\title{
Impaired Synergism between Somatomedin C/Insulin-Like Growth Factor I and Dexamethasone in the Growth of Fibroblasts from a Patient with Insulin Resistance
}

\author{
CHERYL A. CONOVER, RAYMOND L. HINTZ, AND RON G. ROSENFELD \\ Department of Pediatrics, Stanford University Medical Center, Stanford, California 94305
}

\begin{abstract}
To explore a possible mechanism for the diminished growth potential in a patient with an unusual form of insulin resistance, somatomedin $\mathrm{C}$ /insulin-like growth factor I (SM-C/IGF-I) and insulin stimulation of $\left[{ }^{3} \mathrm{H}\right]$ thymidine incorporation and cell replication were compared in skin fibroblasts from the patient (DF) and normal controls. There appeared to be no generalized abnormality in cellular responsiveness to growth factors. In both DF and control cells, SM-C/IGF-I (50 ng/ml), insulin (100 ng/ $\mathrm{ml})$, and epidermal growth factor $(5 \mathrm{ng} / \mathrm{ml})$ stimulated $\left[{ }^{3} \mathrm{H}\right]$ thymidine incorporation 5-, 2-, and 6-fold, respectively. Low concentrations of human hypopituitary serum $(0.25 \%)$ enhanced the effectiveness of SM-C/IGF-I and insulin to a similar extent in both DF and control cells. On the other hand, $10 \%$ calf serum stimulated $\left[{ }^{3} \mathrm{H}\right]$ thymidine incorporation 37-fold in control cells, while DF cells were only $50 \%$ as responsive. Preincubation of control cells with dexamethasone $\left(10^{-7} \mathrm{M}\right)$ caused a marked synergistic increase in SM-C/IGF-I stimulated $\left[{ }^{3} \mathrm{H}\right]$ thymidine incorporation (15- to 20-fold in serum-free medium; 50- to 80-fold in $0.25 \%$ human hypopituitary serum). In contrast, preexposure to dexamethasone did not augment SM-C/IGF-I stimulation of thymidine incorporation into DNA of DF cells. Furthermore, the stimulation of cell replication by SM-C/IGF-I and insulin was potentiated by dexamethasone in control but not DF cultures. These data suggest that impairment of the synergistic action of glucocorticoids with SM-C/IGF-I and insulin regulation of fibroblast growth may be involved in the pathology of this insulinresistant growth disorder. (Pediatr Res 22: 188-191, 1987)
\end{abstract}

\[ \text { Abbreviations } \]
SM-C/IGF-I, somatomedin C/insulin-like growth factor I
EGF, epidermal growth factor
HHS, human hypopituitary serum
SFM, serum-free medium
BSA, bovine serum albumin
IGF-II, insulin-like growth factor II
DMEM, Dulbecco's modified Eagle's medium

We have previously demonstrated that both insulin and SM$\mathrm{C} / \mathrm{IGF}-\mathrm{I}$, at physiological concentrations, are mitogenic for hu-

Received December 4, 1986; accepted March 3, 1987.

Correspondence Cheryl A. Conover, S-322 Department of Pediatrics, Stanford University Medical Center, Stanford, CA 94305.

Supported in part by NIH Grants AG01213, AM33190, AM24085, and AM28229 and the Juvenile Diabetes Foundation Grant 185199. R.G.R. is the recipient of a Research Career Development Award AM01275 from the NIH. man fibroblasts in culture (1). At nanomolar concentrations, each peptide is capable of acting through its own receptor to stimulate DNA synthesis and cell multiplication. Although SMC/IGF-I appears to be the more potent mitogen for human fibroblasts at these concentrations, at supraphysiological concentrations insulin can cross-react with the type I IGF receptor and achieve the same maximal effect as SM-C/IGF-I. Moreover, both insulin and SM-C/IGF-I are synergistic with glucocorticoids in the stimulation of DNA synthesis and replication of normal human fibroblasts, suggesting that the two peptides have a common postreceptor regulatory site in the pathway for mitogenesis.

A recent report (2) described patient DF, a 17-yr-old man, as having growth retardation associated with an unusual form of insulin resistance. This patient had no circulating antibodies directed against either insulin or the insulin receptor, and there was no clinical or laboratory evidence of increases in any hormonal insulin antagonists. Furthermore, despite high circulating insulin values, insulin binding and metabolic responsiveness, as measured by 2 -deoxyglucose uptake into fibroblasts, were normal. SM-C/IGF-I levels were within the normal range.

To explore a possible postreceptor mechanism for this growth disorder, SM-C/IGF-I and insulin stimulation of $\left[{ }^{3} \mathrm{H}\right]$ thymidine incorporation and cell replication were compared in skin fibroblasts from DF and normal controls, under both serum-free and glucocorticoid potentiating conditions.

\section{MATERIALS AND METHODS}

Materials. Thymidine [methyl- ${ }^{3} \mathrm{H}$ ] $(6.7 \mathrm{Ci} / \mathrm{mmol})$ was obtained from New England Nuclear (Boston, MA). Dexamethasone and BSA were purchased from Sigma (St. Louis, MO), and AquaMix was from WestChem (San Diego, CA).

Pure synthetic SM-C/IGF-I was provided by Dr. C. H. Li [San Francisco, CA (3)]. Human insulin was furnished by Eli Lilly Company (Indianapolis, IN) and EGF was purchased from Collaborative Research Inc. (Lexington, MA). The somatomedin preparation designated SM in the text was the Cohn fraction IVI acid-ethanol extract purified short of isoelectric focusing, as previously described (4). This preparation is insulin-free and by specific radioimmunoassays $(5,6)$ the SM-C/IGF-I content was determined to be $25 \mu \mathrm{g} / \mathrm{mg}$ weight and the IGF-II content was $10 \mu \mathrm{g} / \mathrm{mg}$ weight. Earlier studies have shown that this SM has equivalent biological potency in the human fibroblast system to highly purified SM-C/IGF-I preparations $(1,7-10)$.

HHS was obtained from two donors with growth hormone deficiency documented by failure to raise serum growth hormone levels above $7 \mathrm{ng} / \mathrm{ml}$ following arginine and insulin stimulation. IGF-I levels in these sera were less than $25 \mathrm{ng} / \mathrm{ml}$ as determined by radioimmunoassay [normal adult levels range from 150-250 $\mathrm{ng} / \mathrm{ml}(11)]$. 
Cell cultures. Skin fibroblasts from a 17-year-old male patient, designated DF, were obtained from Dr. H. Dean [University of Manitoba, Canada (2)]. Apparently normal human skin fibroblasts from a 24-yr-old man (GM3652) and a 7-yr-old boy (N1493) were purchased from the Human Genetic Mutant Cell Repository (Camden, NJ) and from the American Type Culture Collection (Rockville, MD), respectively. These control cell lines have been characterized extensively in our laboratory in metabolic and mitogenic studies $(1,7-10,12)$.

Cells were cultured in DMEM, supplemented with $100 \mathrm{U} / \mathrm{ml}$ penicillin, $100 \mu \mathrm{g} / \mathrm{ml}$ streptomycin, and $4 \mathrm{mM}$ glutamine (Gibco, Grand Island, NY), and containing $10 \%$ supplemented calf serum (Hyclone Laboratories, Logan, UT) as described previously (7). Cells were trypsinized and plated in $35-\mathrm{mm}$ plastic dishes (Corning, NY) for $\left[{ }^{3} \mathrm{H}\right]$ thymidine incorporation experiments and in 16-mm multiwells (Costar, Cambridge, MA) for replication experiments. Control fibroblasts were used between passages 8 and 14 [less than $30 \%$ of in vitro life span completed (10)]. DF fibroblasts were used between passages 5 and 10 . Although the life span of DF fibroblasts was not investigated, there were no morphological signs of in vitro senescence at these passage levels.

$\left.{ }^{3} \mathrm{H}\right]$ thymidine incorporation. Four days following the last feeding, confluent fibroblast cultures were incubated in DMEM with $0.1 \% \mathrm{BSA}$ and dexamethasone $\left(10^{-7} \mathrm{M}\right)$ or ethanol vehicle $(0.2 \%)$ for $48 \mathrm{~h}$. After this preincubation, the medium was changed to the SFM plus experimental additions. At $21 \mathrm{~h},\left[{ }^{3} \mathrm{H}\right]$ thymidine was added to give a final concentration of $0.2 \mu \mathrm{Ci}$ / $\mathrm{ml}$, and the cells harvested as described in an earlier publication (7). In this system, $\left[{ }^{3} \mathrm{H}\right]$ thymidine incorporation has been shown to peak 21-23 h following stimulation of serum-starved human fibroblasts with SM-C/IGF-I or serum, independent of donor or culture age $(7,8,10,12)$. Results are expressed as the percentage of total counts in the incubation medium which are incorporated into acid-precipitable material per $10^{6}$ cells.

Cell replication. Cells were plated sparsely in a 1:1 mixture (by volume) of Waymouth's medium (Gibco) and DMEM containing $2 \%$ calf serum. The following day, designated day 0 , the cells were washed, cell number was measured, and the medium was changed to Waym:DMEM with $0.1 \%$ BSA plus experimental additions. On day 3, cell number was determined in duplicate wells with a Coulter Counter.

Statistics. Differences between two groups were analyzed using the Student's $t$ test for two independent samples. Results were considered statistically significant when $p<0.05$.

\section{RESULTS}

Effect of somatomedin, insulin, EGF, and serum on $\left.{ }^{\beta} H\right]$ thymidine incorporation. The stimulation of $\left[{ }^{3} \mathrm{H}\right]$ thymidine incorporation in DF and control fibroblasts by SM, insulin, and EGF alone, or by SM and insulin in combination with low concentrations of serum is shown in Figure 1. In SFM, the

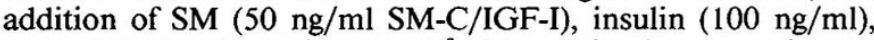
and EGF $(5 \mathrm{ng} / \mathrm{ml})$ stimulated $\left[{ }^{3} \mathrm{H}\right]$ thymidine incorporation $5-$, $2-$, and 6-fold, respectively. There was no significant difference between DF and control fibroblasts in their responsiveness to these growth factors.

HHS, at very low concentrations, has been shown to enhance the mitogenic effect of SM-C/IGF-I and insulin in normal human fibroblasts (1). HHS $(0.25 \%)$ alone stimulated $\left[{ }^{3} \mathrm{H}\right]$ thymidine incorporation 3-fold in control and DF cells. HHS potentiated SM action to 26-fold in control cells and to 16-fold in DF cells. Although the difference in responsiveness of DF and control cells to SM + HHS is significant in this experiment, this was not a consistent finding (see Fig. 2) and the magnitude of the effect in DF cells is within the normal range for cultured human fibroblasts (8). HHS enhanced insulin's effect to 11 -fold in both DF and control cells. However, DF cells were only $50 \%$ as responsive as normal fibroblasts to the mitogenic effect of $10 \%$ calf serum $(p<0.001)$.

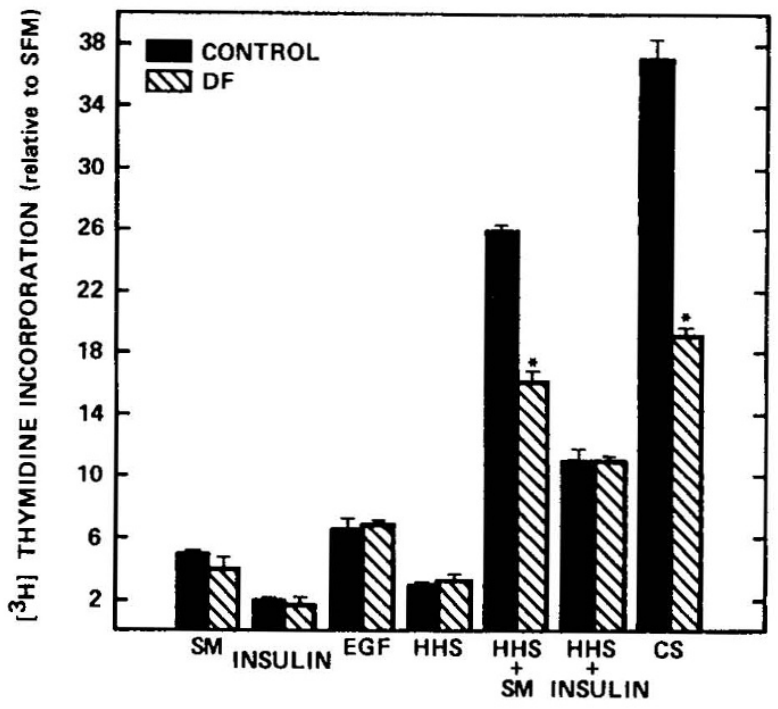

Fig. 1. Effect of somatomedin, insulin, EGF, and serum on $\left[{ }^{3} \mathrm{H}\right]$ thymidine incorporation in DF and control fibroblasts. Human fibroblasts were plated in $35-\mathrm{mm}$ dishes and grown to confluency. The cells were then serum-starved for $48 \mathrm{~h}$, and the medium changed to the indicated experimental medium. $\left[{ }^{3} \mathrm{H}\right]$ thymidine incorporation was measured at 21-23 h. Results are the means \pm SEM of three determinations expressed relative to SFM (which is assigned an arbitrary value of 1.0 ). $\left[{ }^{3} \mathrm{H}\right]$ thymidine incorporation values for SFM were 0.82 and 0.31 per $10^{6}$ cells for DF and control (GM3652) cultures, respectively. SM, $50 \mathrm{ng} / \mathrm{ml}$ SM-C/IGF-I; insulin, $100 \mathrm{ng} / \mathrm{ml}$; EGF, $5 \mathrm{ng} / \mathrm{ml}$; HHS, $0.25 \%$ HHS; CS, calf serum, $10 \%$. *indicates a significant difference between DF and control cells at $p<0.001$.

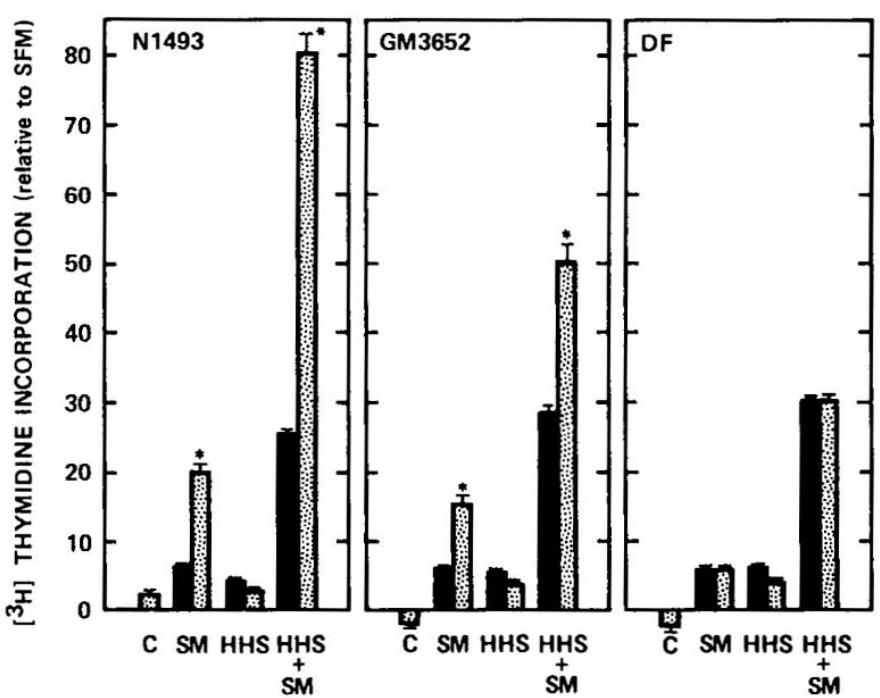

Fig. 2. Effect of dexamethasone on somatomedin stimulation of $\left[{ }^{3} \mathrm{H}\right]$ thymidine incorporation. Fibroblasts were treated as described in Figure 1. Confluent cultures were serum starved with $10^{-7} \mathrm{M}$ dexamethasone (stippled bars) or ethanol vehicle (solid bars) for $48 \mathrm{~h}$ and the medium then changed to the experimental medium. $\left[{ }^{3} \mathrm{H}\right]$ thymidine incorporation was measured at 21-23 h. Results are means \pm SEM of three determinations expressed relative to SFM (which is assigned an arbitrary value of 1.0 ). $\left[{ }^{3} \mathrm{H}\right]$ thymidine incorporation values for SFM were $0.11,0.48$, and 0.47 per $10^{6}$ cells for N1493, GM3652, and DF cultures, respectively. $\mathrm{SM}, 50 \mathrm{ng} / \mathrm{ml} \mathrm{SM}-\mathrm{C} / \mathrm{IGF}-\mathrm{I}$; HHS, $0.25 \%$ human hypopituitary serum. *indicates a significant difference with dexamethasone at $p<0.001$. 
Effect of dexamethasone on somatomedin stimulation of $\left[{ }^{\beta} \mathrm{H}\right]$ thymidine incorporation. Glucocorticoids have been shown to be necessary for optimal somatomedin stimulation of DNA synthesis in normal human fibroblasts in vitro (7). Thus, the interaction between SM and dexamethasone was investigated in DF fibroblasts (Fig. 2). In accordance with the results shown in Figure 1, SM $\left(50 \mathrm{ng} / \mathrm{ml} \mathrm{SM-C/IGF-I)} \mathrm{alone} \mathrm{stimulated}\left[{ }^{3} \mathrm{H}\right]\right.$ thymidine incorporation 6-fold in DF and the two control cell lines. Furthermore, all three cell lines were responsive to the enhancing effect of HHS on SM action, with SM $+0.25 \%$ HHS stimulating $\left[{ }^{3} \mathrm{H}\right]$ thymidine incorporation $25-, 28-$, and 30 -fold in N1493, GM3652, and DF cultures, respectively.

Dexamethasone $\left(10^{-7} \mathrm{M}\right)$ alone had no stimulatory effect on $\left[{ }^{3} \mathrm{H}\right]$ thymidine incorporation in control or patient cells. However, preincubation of normal human fibroblasts lines N1493 and GM3652 with dexamethasone resulted in a dramatic synergistic increase in SM-stimulated $\left[{ }^{3} \mathrm{H}\right]$ thymidine incorporation. In control cells pretreated with dexamethasone, SM $(50 \mathrm{ng} / \mathrm{ml}$ SM-C/IGF-I) stimulated $\left[{ }^{3} \mathrm{H}\right]$ thymidine incorporation $15-$ and 20 -fold in SFM and 50- and 80 -fold in the presence of $0.25 \%$ HHS. In contrast, preincubation of DF cells with dexamethasone had no effect on SM stimulation of $\left[{ }^{3} \mathrm{H}\right]$ thymidine incorporation in either SFM or with $0.25 \%$ HHS. In this experiment, $\left[{ }^{3} \mathrm{H}\right]$ thymidine incorporation was measured at $21-23 \mathrm{~h}$, however, this lack of synergistic action between SM and dexamethasone was evident in DF fibroblasts even when $\left[{ }^{3} \mathrm{H}\right]$ thymidine incorporation measurements were taken up to $32 \mathrm{~h}$ following SM stimulation (data not shown).

Effect of pure SM-C/IGF-I on the replication of human fibroblasts. The $\left[{ }^{3} \mathrm{H}\right]$ thymidine incorporation experiments presented in Figures 1 and 2 were performed using a preparation of SM which was a mixture of both SM-C/IGF-I and IGF-II. Table 1

Table 1. Effect of IGF-I, insulin, and dexamethasone on the replication of human fibroblasts*

\begin{tabular}{lcc}
\hline & \multicolumn{2}{c}{ Cell no. $\left(\times 10^{5}\right)$} \\
\cline { 2 - 3 } & Control & DF \\
\hline EtOH & $0.24(100)$ & $0.40(100)$ \\
DEX & $0.20(83)$ & $0.34(83)$ \\
SM-C/IGF-I & & \\
SM-C/IGF-I + DEX & $0.34(142)$ & $0.53(131)$ \\
Insulin & $0.44(183)$ & $0.55(137)$ \\
Insulin + DEX & $0.32(133)$ & $0.47(117)$ \\
HHS & $0.40(167)$ & $0.51(128)$ \\
HHS + DEX & & \\
SM-C/IGF-I + HHS & $0.34(142)$ & $0.44(110)$ \\
SM-C/IGF-I + HHS + DEX & $0.29(121)$ & $0.41(102)$ \\
Insulin + HHS & $0.54(225)$ & $0.62(156)$ \\
Insulin + HHS + DEX & $0.79(329)$ & $0.65(162)$ \\
10\% calf serum & $0.59(245)$ & $0.57(142)$ \\
\hline
\end{tabular}

${ }^{*}$ Fibroblasts were plated sparsely in $2 \%$ calf serum. Cells were allowed $24 \mathrm{~h}$ to attach, washed, and the medium changed to the indicated experimental medium. The number in parenthesis is the cell number on day 3 expressed as the percent of cell number in SFM on day 3 (which has been assigned an arbitrary value of $100 \%$ ). Results are the average of duplicate wells. Percent variation (difference between observations divided by the mean $\times 100$ ) was less than $10 \%$.

EtOH, $0.2 \%$ ethanol; DEX, $10^{-7}$ dexamethasone; SM-C/IGF-I, 100 $\mathrm{ng} / \mathrm{ml}$; insulin, $100 \mathrm{ng} / \mathrm{ml}$; HHS, $0.25 \%$. corroborates these results using a pure synthetic SM-C/IGF-I and includes data showing the effect of insulin and SM-C/IGF-I on replication of DF and control fibroblasts. SM-C/IGF-I (100 $\mathrm{ng} / \mathrm{ml})$ and insulin $(100 \mathrm{ng} / \mathrm{ml})$ increased cell number 42 and $33 \%$, respectively, in control cultures. In the presence of $0.25 \%$ HHS, SM-C/IGF-I and insulin increased cell number 125 and $100 \%$, respectively, in control cultures. DF fibroblasts were capable of responding to the mitogenic effects of SM-C/IGF-I and insulin and to express synergism between $0.25 \%$ HHS and SM$\mathrm{C} / \mathrm{IGF}-\mathrm{I}$ and insulin. However, when cell number was expressed as percent of serum-free medium, the DF responsiveness appeared to be less than control cells, especially in the presence of $0.25 \%$ HHS which alone had only a $10 \%$ effect in DF cells compared to a $42 \%$ effect in control cells.

Dexamethasone alone had a slight inhibitory effect on cell replication. However, SM-C/IGF-I + dexamethasone increased control cell number $83 \%$ in SFM and $229 \%$ in the presence of $0.25 \%$ HHS. Dexamethasone also potentiated insulin's mitogenic effect in control cells. In contrast, dexamethasone had little effect on SM-C/IGF-I or insulin stimulation of DF cell replication.

Also shown in Table 1, the increase in cell number in response to serum was $58 \%$ less in DF as compared to control cultures.

\section{DISCUSSION}

Tokuhiro et al. (2) described patient DF as having growth retardation associated with severe insulin resistance. None of the usual causes, such as naturally occurring antibodies against insulin or the insulin receptor, abnormal forms of circulating insulin, or increased levels of insulin antagonists could be found to explain this unusual disorder. Insulin binding and insulinstimulated glucose transport were normal. Circulating levels of SM-C/IGF-I, a biochemical relative of insulin, were found to be normal. The authors proposed an undefined postreceptor defect as the cause of the abnormal growth condition. The data presented herein suggest one possible mechanism for impaired cellular growth in DF.

Fibroblasts from DF appeared to have normal increases in $\left[{ }^{3} \mathrm{H}\right]$ thymidine incorporation in response to SM-C/IGF-I, insulin, and EGF in SFM. DF and control cells also showed similar enhanced responsiveness to SM-C/IGF-I and insulin in the presence of $0.25 \%$ HHS. Therefore, the ability of SM-C/IGF-I, insulin, and EGF to stimulate DNA synthesis in DF fibroblasts was not consistent with a generalized defect in growth factor responsiveness in these cells.

When control fibroblasts were preincubated with dexamethasone and then stimulated with SM-C/IGF-I, both in SFM and in the presence of $0.25 \%$ HHS, there was a striking synergistic increase in $\left[{ }^{3} \mathrm{H}\right]$ thymidine incorporation. Dexamethasone also potentiated SM-C/IGF-I-stimulated multiplication of control cells. In contrast, in DF cells, preincubation with dexamethasone produced little or no enhancement of SM-C/IGF-I stimulation of DNA synthesis or fibroblast replication. Similarly, insulin in the presence of dexamethasone produced a synergistic increase in cell number in control cells, while in DF cells this synergism was impaired.

The defect in DF fibroblast mitogenesis appears to be distal to the insulin and SM-C/IGF-I receptor and on a specific pathway leading to DNA synthesis which is common to the action of SM$\mathrm{C} / \mathrm{IGF}-\mathrm{I}$ and insulin. Evidence that the defect is specific for DNA synthesis includes previous findings that glucocorticoids do not alter SM-C/IGF-I binding or SM-C/IGF-I stimulation of RNA and protein metabolism in normal human fibroblasts (1) and that insulin-stimulated glucose uptake was not altered in DF cells (2).

Both the experiments presented here and the study of Tokuhiro et al. (2) demonstrated a $40-60 \%$ decrease in $\left[{ }^{3} \mathrm{H}\right]$ thymidine incorporation and replication of DF cells in response to serum. 
These observations with serum may be related, in part, to the interaction of SM-C/IGF-I and insulin with glucocorticoids in the regulation of fibroblast growth. The concentration of hydrocortisone in adult human serum ranges from $22-226 \mu \mathrm{g} /$ liter (60-600 nM). Parenthetically, subject DF had hydrocortisone levels within the normal range (2). Although in these experiments a concentration of dexamethasone was used which was found to produce a maximal effect $(100 \mathrm{nM})$, earlier studies have shown a significant effect on SM-C/IGF-I stimulation of fibroblast replication with as little as $1 \mathrm{nM}$ dexamethasone and $10 \mathrm{nM}$ hydrocortisone (7). Physiological concentrations of glucocorticoids also have been shown to influence cell growth in other culture systems. The nature of the response, whether stimulatory or inhibitory, varies according to the cell type and culture conditions (13-15).

The present study was limited to fibroblast cultures. Nevertheless, this is the first report in which a postreceptor alteration in the interaction between SM-C/IGF-I or insulin and glucocorticoids may be linked to abnormal mitogenic action in a pathological growth state. On the other hand, the effects of SM-C/ IGF-I and dexamethasone on DNA synthesis and replication of fibroblasts from DF share many similarities with the effects of these hormones on fibroblasts from aged individuals [donors $85-$ $96 \mathrm{yr}$ old $(8,12)]$. Thus, in both situations, the response to SMC/IGF-I alone and SM-C/IGF-I in the presence of $0.25 \%$ HHS was normal. However, there was a loss of synergism between SM-C/IGF-I and dexamethasone in promoting DNA synthesis and replication of fibroblasts from DF and old donors. The cellular mechanism for the mitogenic interplay between SM-C/ IGF-I and glucocorticoids in human fibroblasts and the nature of the defect(s) in the regulatory scheme in insulin resistance, aging, and possibly other growth-deficient states are important research concerns currently under investigation.

Acknowledgments. The authors thank Dr. Heather Dean and Yvette Perry (University of Manitoba, Manitoba, Canada) for generously providing us with fibroblasts from patient DF.
REFERENCES

1. Conover CA, Hintz RL, Rosenfeld RG 1985 Comparative effects of somatomedin $\mathrm{C}$ and insulin on the metabolism and growth of cultured human fibroblasts. J Cell Physiol 122:133-141

2. Tokuhiro E, Dean H, Winter J, Haworth JC, Imai Y, Friessen HG 1984 A new form of insulin resistance with growth retardation, fatty liver, and hypogonadotropic hypogonadism. Pediatr Res 18:670-674

3. Li CH, Yamashiro D, Gospodarowicz D, Kaplan SL, Val Vliet G 1983 Total synthesis of insulin-like growth factor I (somatomedin C). Proc Natl Acad Sci USA 80:2216-2220

4. Rosenfeld RG, Dollar LA 1982 Characterization of the somatomedin-C/ insulin-like growth factor I (SM-C/IGF-I) receptor on cultured human fibroblast monolayers: regulation of receptor concentrations by SM-C/IGFI and insulin. J Clin Endocrinol Metab 55:434-440

5. Furlanetto RW, Underwood LE, Van Wyk JJ, D'Ercole AJ 1977 Estimation of somatomedin C levels in normals and patients with pituitary disease by radioimmunoassay. J Clin Invest 60:648-657

6. Hintz RL, Liu F 1982 A radioimmunoassay for IGF-II specific for the Cpeptide region. J Clin Endocrinol Metab 54:442-446

7. Conover CA, Dollar LA, Hintz RL, Rosenfeld RG 1983 Insulin-like growth factor $\mathrm{I} /$ somatomedin $\mathrm{C}$ and glucocorticoids synergistically regulate mitosis in competent human fibroblasts. J Cell Physiol 116:191-197

8. Conover CA, Dollar LA, Rosenfeld RG, Hintz RL 1985 Somatomedin C binding and action in fibroblasts from aged and progeric subjects. J Clin Endocrinol Metab 60:685-691

9. Conover CA, Rosenfeld RG, Hintz RL 1986 Hormonal control of the replication of human fetal fibroblasts: role of somatomedin C/insulin-like growth factor I. J Cell Physiol 128:47-54

10. Conover CA, Rosenfeld RG, Hintz RL 1987 Somatomedin C/insulin-like growth factor I binding and action in human fibroblasts aged in culture: impaired synergism with dexamethasone. J Gerontol 42:308-314

11. Zapf J, Walter H, Froesch ER 1981 Radioimmunological determination of insulin-like growth factors I and II in normal subjects and in patients with growth disorders and extrapancreatic tumor hypoglycemia. J Clin Invest 68:1321-1330

12. Conover CA, Rosenfeld RG, Hintz RL 1985 Aging alters somatomedin C. dexamethasone synergism in the stimulation of deoxyribonucleic acid synthesis and replication of cultured human fibroblasts. J Clin Endocrinol Metab 61:423-428

13. Cristofalo VJ, Wallace JM, Rosner BA 1979 Glucocorticoid enhancement of proliferative activity in WI-38 cells. In: Sato GW, Ross R (eds) Hormones and Cell Culture. Cold Spring Harbor, New York, 6:875-886

14. Runikis JO, McLean DI, Stewart WD 1978 Growth rate of cultured human skin fibroblasts increased by glucocorticoids. J Invest Dermatol 70:348-35

15. Thrash CR, Cunningham DD 1973 Stimulation of division of density inhibited fibroblasts by glucocorticoids. Nature 242:399-401 